\title{
Consuming Capitalist Modernity in the Media Cultures of 1930s and 1960s Manila's Commercial Streets
}

\section{ELMO GONZAGA}

Tracing the entangled genealogies of spaces of media spectatorship, modes of visual perception, and practices of capitalist consumption, this article explores how the shift in Manila's main commercial street from Calle Escolta in the 1930s to Avenida Rizal in the 1960s reveals changes in the imagination and experience of capitalism and modernity. Previously embodied in the infrastructure, architecture, and technology of the cityscape, which only government and business were perceived as having the capacity to produce, modernity became reconfigured as a dynamic force that ordinary residents came to believe they could harness. The article comparatively analyzes variations and dissonances in the print and audiovisual media of the two periods, particularly in the contrasting representations of awkward vaudeville comedians and youthful movie antiheroes. Instead of treating consumer and media culture as a source of docility and atomization, it sees the collective spectatorship of mass entertainment as generating the potential for selftranscendence and revolution.

Keywords: capitalism, cities, consumption, media, modernity, Philippines, spectatorship

\begin{abstract}
A DJaCENT TO EACH OTHER, metropolitan Manila's two main commercial streets, entrenched in the collective imagination of the city, represent the passage in the prevailing form of modernity between two important periods in the world history of capitalism in the twentieth century. Frequenting these bustling public spaces to discover the latest products, styles, and technologies, ordinary Filipinos encountered the multiple possibilities for agency produced by urban flows. Whereas Calle Escolta in the 1930s was defined by the progress witnessed in the imposing achievements of its art deco buildings and window displays, Avenida Rizal in the 1960s was characterized by the self-fashioning facilitated by the affordable products of its retail emporiums and movie theaters.

Most scholarship about modernity in the cities of the Global South could be described as falling under two categories. Focused on its emergence in the early twentieth century, the first set of studies (Lee 1999; Mrázek 2002) explores how the introduction of new infrastructures and technologies of transportation, leisure, and communication into the urban environment became experienced almost as a relentless, dynamic force, which transformed the dominant modes of perception. The other category is concerned with the late twentieth century, particularly the expansion of electronic media and the onset of neoliberal capitalism. Such studies (Appadurai 1996; Canclini 1995) examine
\end{abstract}

Elmo Gonzaga (egonzaga@cuhk.edu.hk) is Assistant Professor in the Department of Cultural and Religious Studies at The Chinese University of Hong Kong. 
how the transmission and dissemination of media content across multiple platforms and locations have allowed global flows formerly accessible only to a limited, more affluent few to be harnessed in vernacular terms. Writings in these two types of scholarship tend to comprehend modern forces as being intrinsically shaped by consumer practices and media technologies. Whereas the first regards modernity as a sweeping, transcendent process, which arrives from outside the territorial domain, the second considers it to have a contingent, malleable potential, which is incarnated through bodily gestures and actions.

Instead of enumerating factors that would account for the shift between these two regimes with sociological comprehensiveness or teleological historicization, I describe variations and dissonances in the forms and meanings of consumer spaces and practices (Zhang 2005, 11). Aspiring for a panoramic view of each period that would constitute what Raymond Williams (1977, 128-35) calls its structure of experience, I tried to locate images, discourses, and narratives of the prevalent forms of entertainment, spaces of exhibition, and modes of spectatorship. My method entailed delving into the archive to peruse a wide range of print and audiovisual media over a span of several years from each period-particularly newspapers, films, photographs, and advertisements - to be able to uncover recurrent patterns among salient representations of modern urban life. In my discussion of each milieu, I selected artifacts that could be said to have captured the collective imagination of the time because of their repeated inscription in the public culture.

Refraining from treating the effects of consumer and media products as deterministic in engendering docility and atomization among ordinary people, I understand them to be transformative in their fostering of creativity and possibility. In this article, I examine the concomitant rise of consumer and media cultures in a Southeast Asian city by uncovering the configurations of commercial spaces that engrossed the collective imagination in two important historical moments. The surrounding environments of commercial spaces acted as sites of convergence and negotiation for capitalist flows, in which urban residents made sense of modern forces in different ways through their variable consumption of such products.

The city I focus on is Metro Manila, capital of the Philippines, long called the "Sick Man of Asia" for the tentativeness of its political governance and economic growth. The Philippines is now targeted as a lucrative site for foreign investment because of its burgeoning consumer-based domestic economy, which has been fueled by the remittances of overseas migrant workers and the salaries of call center agents. The economic importance of commercial consumption is evinced by the fact that the archipelagic nation has three of the largest shopping malls in the world, all of which, found in Metro Manila, now function as the principal hubs of social life in the congested megalopolis. Looking at the predominant consumer spaces prior to the shopping mall, I explore how the transition in Manila's main commercial street from Calle Escolta in the 1930s to Rizal Avenue in the 1960s may have corresponded with the passage to mass-based regimes of capitalism, consumption, and entertainment.

The 1930s and 1960s represent two junctures in Philippine history when the possibilities offered by modernity seemed boundless before the traumas of the Pacific War in the 1940s and Martial Law in the 1970s. When the Philippines Islands obtained commonwealth status in the 1930s, the US colony found itself on a definite path toward political 
independence after more than three decades of colonial rule. This period immediately preceded the devastation of the Pacific War, which profoundly impacted not only the economy but also the culture of both the city and the archipelago. By the 1960s, the trauma of war had yielded to the promise of upheaval, which put forward a new paradigm of modernity. The independent Filipino nation would frequently be exalted in periodicals as the second most prosperous economy in Asia next to Japan due to its protections over its local industries. The excitement and ferment of the time culminated in the declaration of martial law by the corrupt and oppressive Marcos dictatorship, which led to economic decline and political turmoil. Marking important historical moments, these shifts coincided with changes to the prevalent consumer and media cultures from luxury to mass consumption and from theater to film entertainment. However, instead of presuming a seamless, linear continuity, I consider how different historical periods could be taken as distinct social milieus, each with its own defining sets of mediated conditions and tendencies.

While the urban nucleus has since shifted to Epifanio de los Santos Avenue, which connects Metro Manila's different cities and municipalities, Calle Escolta and Rizal Avenue continue to figure prominently in social media through nostalgic photographs and narratives, which eulogize the so-called golden age of Manila. Departing from these sentimental reminiscences, I would like to see prior urban spaces as dynamic sites of transition and transformation, where the parameters and possibilities of identity and collectivity in different historical milieus are disclosed. As such, this article is divided into two main sections, in which each milieu is examined according to its predominant spaces of commerce and leisure and practices of consumption and spectatorship.

\section{0s Calle Escolta: Modernity as Divine Intervention}

Into the fourth decade of US rule, the compact Calle Escolta had developed into the center of finance and commerce in Manila, the capital of the Philippine Islands. Despite being only half a kilometer long and twenty meters wide (Sunday Times Magazine 1950, 23), the commercial street had attained prestige and prominence for being lined with shops that sold imported luxury goods. Called the "Queen of the Streets," the Escolta was renowned for being the main destination in the city where members of the social and economic elite could enhance their distinction by acquiring objects that displayed their material wealth. As new buildings and establishments that displayed modern architectural styles, technological advances, and commercial fashions would be constructed through the 1930s, it was transformed into an exemplar not only of luxury but also of progress. Forming the urban nucleus for commerce and consumption, Calle Escolta served as a public space where ordinary Filipino consumers could encounter and negotiate the arrival of modern forces. Whereas modernity would become embodied in the infrastructure, architecture, and technology of the cityscape through the interventions of government and business, individuals struggled to harness the possibilities of modernity through their consumption of commercial and media products.

Running parallel to the Pasig River, a major tributary that flowed in from the South China Sea, the Escolta was anchored by two busy public squares, Plaza Moraga on the west and Plaza Goiti on the east. Plaza Moraga connected Calle Escolta with Calle 
Rosario (now Quintin Paredes Street), which was the main commercial street under the Spanish regime with shops run by the local Chinese community. Plaza Goiti (now Plaza Arsenio Lacson) functioned as the central hub of the tranvia tramway line, which provided mass transit to different parts of the city such that the terminuses of its network came to be seen as the "ends of the earth" (De Manila 1977b, 258) or the limits of civilization. Plaza Goiti was adjacent to Plaza Santa Cruz, a famous destination for popular entertainment, which then led to the burgeoning thoroughfare of Avenida Rizal.

As the main commercial street of the capital city, Calle Escolta epitomized the transcendent intervention of modernity in early twentieth-century Philippines. The Spanish colonial era from the sixteenth to nineteenth centuries was marked by recurrence and stagnation. Due to their inherent fragility, physical structures during this historical period often failed to overcome the seemingly fated rhythm of periodic catastrophes. Majestic state and church structures built of wood, stone, or adobe tended to be damaged or demolished by typhoons, fires, and earthquakes (Ventura 1978, 197-201). The local populace experienced time as an inevitable cycle in which newly built structures would eventually be destroyed through the agency of nature and the sanction of God. José Rizal's (2006, 201-9) seminal 1887 novel Noli Me Tangere illustrates how such catastrophes would be attributed by Catholic friars in their homilies to the innately sinful thoughts and actions of natives. This cyclicality was echoed in the immobility of society, as individuals stayed bound to their given circumstances throughout their lifespan. The narrative arcs of characters like Sisa and Basilio exemplify how most natives subsisted with scarce hope of ascending through the established hierarchy, which was dominated by landowners and friars of Spanish descent.

With the US occupation of the Philippines in the last decade of the nineteenth century, the landscape of the archipelago appeared to be transformed. Departing from the perceived inertia of the earlier regime, the new colonial government extensively and effectively introduced advances in infrastructure and transportation conventionally recognized as modern. Its distinction from Spanish rule was remarkably evident due to the lasting changes to everyday life it managed to deliver to a stagnant landscape. Assuming the force and veneer of divine intervention to a predominantly Catholic populace, it brought electricity to streets, buildings, and homes. Enhancing mobility, it paved and illuminated the roads to ensure the quick and efficient movement of bodies and goods. Under US rule, wood, stone, and adobe structures were reborn with iron, glass, and concrete.

As the new regime effectively reconfigured bodies, spaces, and practices with modern norms, Filipinos learned to equate modernity with the United States (Pérez 1999). From the beginning of its rule in the early twentieth century, the US colonial government set up extensive public education and civil service systems (Kramer 2006, 166-70, 201-3). Akin to the work of national periodicals, public schools trained Filipinos in the rudiments of modernity, such as modern ways of inhabiting spaces and managing emotions. The efficacy of the state's influence suggested the impossibility of controlling or harnessing unfamiliar modern forces on the part of individuals, which added to the inexorable, monolithic, and almost supernatural character of progress. Laikwan Pang (2012, 31) describes how modernity was conceived early on as a creative agency that only divine beings possessed the capacity to wield. This common perception of modernity as having an unattainable transcendence would be reflected in public imagery such as Rising 
Philippines, a mural by Filipino modernist painters Victorio C. Edades, Carlos V. Francisco, and Galo B. Ocampo in the lobby of the 1935 Capitol Theater, which depicted a female colossus ascending from the materiality of national history toward the future of heavenly salvation.

Despite the seemingly boundless promise evoked by these numerous changes, the decade leading up to the Pacific War was an ambivalent moment for many Filipinos. Although the Philippines Islands had experienced an economic boom in the interwar period, the aftereffects of the global economic depression at the end of the 1920s lingered into the succeeding decade in the form of salary reductions, and thus less purchasing power for consumers (Doeppers 1984). Anxieties over the future worsened when the colony was granted a definite path toward political independence with commonwealth status in 1935. Periodicals expressed the growing apprehension that the national economy would falter without the steady, duty-free demand of US markets for Filipino agricultural raw materials, such as sugar, hemp, coconut oil, and copra. Politicians and journalists debated extending the run-up to independence if not overturning independence altogether.

Amid the anxieties of the period, Calle Escolta continued to epitomize progress in 1930s Manila with its innovations in architecture, technology, and commerce. In the late nineteenth century, Calle Escolta had garnered fame for luxury shops such as Puerta del Sol and La Estrella del Norte (Agoncillo 2003, 330-31), whose advertisements highlighted the sale of "the finer things in life," namely exquisite jewelry, clocks, perfumes, porcelain, and silverware. Stored in the hidden backrooms of shops but displayed on the bodies of their wealthy owners, luxury goods enhanced social distinction because they remained inaccessible and invisible to most of the populace. In contrast, progress derived its meaning from its extensive visibility. Aside from being built from state-of-the-art materials like plate glass and reinforced concrete, its structures emulated prominent commercial buildings in the United States by featuring the emergent technology of air-conditioning, which together constituted an unequivocal material presence (Leach 1993, 302-5). Standing close to Plaza Goiti, the prominent Heacock's department store occupied the seven-story Heacock Building, which was known for its wall-high window displays and automatic electronic doors (José 2004). The department store carried a selection of fashionable products, such as watches, bicycles, iceboxes, fountain pens, and photographic equipment, which were marketed in print advertisements as characteristic objects of modernity.

Situated at the midpoint of the Escolta, the Crystal Arcade was the most striking building on the commercial street with its sweeping horizontal lines and circular edges. When it was inaugurated on June 1, 1932, it was extolled in local newspapers (Manila Daily Bulletin 1932, 4) as being the exemplar of progress in the cityscape. Designed by Filipino architect Andrés Luna de San Pedro, whose family owned the property, the Crystal Arcade housed the Manila Stock Exchange, the financial nucleus of the decade's gold-mining boom. Costing P1.5 million to construct, the fully air-conditioned, art deco building was christened a "new paradise for shoppers."

Faithful to the name of the building, its majestic interior was a study in glass and lighting, which evoked the grand department stores of Paris and New York (Leach 1993, 71-84). Each story formed a glistening wall of Belgian plate glass. To augment the radiance of the interior, insets of prismatic glass had been built into the floor. 
Hanging from the front and rear of its palatial atrium were resplendent German glass skylights, which were ringed by bands of triangles and diamonds with dual tones of blue, green, rose, yellow, white, and orchid. With a total cost of P180,000 at the time, more plate glass was reportedly used in the Crystal Arcade than in all the structures on Calle Escolta combined.

According to its builders, the Crystal Arcade represented "the last word in modernity." Its physical structure was engineered to withstand Manila’s recurrent catastrophes, which had resulted in the destruction of monumental architecture in the past. Made of durable reinforced concrete, it illustrated the strength of locally produced Rizal cement, which was claimed to be resistant to damage from a range of external forces, from automobile tires to earthquake tremors. Its basement was equipped with drainage pumps to prevent flooding, which happened occasionally on the Escolta during the monsoon season due to overflowing canals.

I would argue that modern forces proved to be less manageable for individuals than for government and business, which wielded vast authority over financial and material resources. Displaying their own capacity for harnessing the possibilities of modernity was one way for Filipinos to demonstrate their readiness for sovereignty. In reconfiguring customs and habits, the US administration aimed to mold weak, filthy, and immature natives into productive, orderly, and hygienic citizens (Anderson 2006, 71). Emphasizing the link between proper sanitation and modern civilization, for instance, the new public education and health systems trained Filipinos to wear clean clothes and wash their hands (Anderson 2006, 115-17). Filipinos' innate capacity for mimicry was supposed to enable to them to acquire modernity and independence without delay.

Filipino businesses were often described as being less prosperous and capable than their Chinese and Japanese competitors (Doeppers 1984, 18, 58). Before the Pacific War, local participation in the wholesale and retail businesses respectively comprised only 20 percent and 80 percent of the total. Articles in newspapers and magazines frequently discussed why Filipinos had failed to achieve a higher level of economic success. While Filipinos lacked the same access to overseas suppliers (Doeppers 1984, 58), they were criticized for being inherently "sentimental," a trait that supposedly caused them to become "impractical" and "unbusinesslike" (Philippines Herald Yearbook 1933, 14). According to this notion, effective commerce relied on a professional demeanor whose rationality and pragmatism meant not being easily overwhelmed by emotional attachments to traditional structures and contingent circumstances when the moment called for decisive action. In the public culture, excessive sentimentality was portrayed as the main obstacle that kept Filipinos from developing the capacity to govern a politically independent nation and financially prosperous economy.

Serving as indexes, dictionaries, and manuals of modernity, local newspapers strove to educate their Filipino readers about objects, attitudes, words, and practices deemed to be new or innovative (Cohen 2006, 11). The most respected periodicals during the 1930s published in English, the established language of modernity in the Philippine Islands. When the monthly Philippine Magazine claimed that its audience was the "most wideawake and progressive people in the Far East," it contrasted modern consciousness and activity against the slumber of tropical inertia. The Sunday edition of The Tribune devoted regular sections to modern science, youth, and women that highlighted the norms of modernity. Aside from espousing the virtues of rationality and efficiency, they 
instructed different segments of the populace about the proper means by which they could negotiate rapidly shifting circumstances. Like in the case of Cuba, another colony, US culture furnished a concrete measure for achievable goals of material progress (Pérez 1999, 60-61). From the standpoint of colonial officials, however, because Filipinos were inherently primitive and immature, they could never be fully assimilated into a state of civilization (Anderson 2006; Kramer 2006). Any natural incapacity for order or hygiene could be compensated for only by using technological implements such as consumer goods.

Believed to be controllable only by government and business in their construction of the infrastructure, architecture, and technology of the cityscape, modernity appeared to render ordinary residents unable to harness its potential with their own capacities. Equipped with increased purchasing power as members of the growing workforce, Filipinos could not avoid dealing with modern forces when inhabiting commercial spaces, purchasing imported products, and adopting urban lifestyles. For most, their personal encounter with modernity was troublesome and tentative, a situation that was culturally represented less by the exploits of heroic demigods than by the misfortunes of humorous caricatures in the public culture of the time. While seemingly frivolous and insignificant, these comic figures served as vernacular models of conduct, which demonstrated how awkwardness and embarrassment could be acceptable responses in dealing with modern forces.

One such paradigmatic figure of modernity was Kenkoy, the gangling protagonist of Tony Velasquez's comic strip Album ng Kabalbalan (Album of Follies), which started being serialized in the popular Tagalog-language Liwayway magazine in the 1930s. Kenkoy represented the almost comic awkwardness of the attempt to grapple with modernity. Derived from characters in folk narratives (S. Reyes 2009, 395), he epitomized the ordinary consumers who would frequently encounter the miracles of electronic technology on the Escolta. Illustrating how capitalist consumption entails self-fashioning, his spontaneous response as a consumer of styles to the proliferation of modern flows is expressed through an exaggerated physicality. He could be regarded as the literary transfiguration of a popular vaudeville performer, who humorously incorporates a panoply of incongruous influences into his appearance and demeanor.

In the 1920s, a local variant of vaudeville called bodabil had flourished in Plaza Santa Cruz at one end of the Escolta, replacing the sarswela, an indigenized opera derived from Spanish theater, as the primary form of cultural entertainment in Manila (Philippines Free Press 1932b, 5). Originating as an intermission between zarzuela performances or movie shorts, vaudeville captivated Filipino crowds with its bawdy, boisterous medley of music, dance, magic, acrobatics, and comedy (Maglipon 1993, 95). As a popular form of entertainment, vaudeville was supposedly influenced by amusement parks like New York's Coney Island, which shared its characteristic modern logics of heterogeneity, novelty, and exuberance (R. Lewis 2003, 15, 319-20). A typical performance consisted of an assortment of short, improvised acts, which had no overall narrative coherence (Jenkins 1992, 123). Performed as a burst of fervent energy (Jenkins 1992, 9), each act needed to be strikingly different from the other acts to sustain the enthusiasm of the audience throughout the entire performance (R. Lewis 2003, 337).

One of the most successful bodabil performers in Manila during this period was Canuplin, the "Fabulous Magician," who was an indigenized caricature of Charlie Chaplin. 
Garbed in the trademark oversized coat and pants, his moustache exaggeratedly drawn, he had a unique talent for eliciting laughter from his audiences (Maglipon 1993, 95). Global in his appeal and reach, he would tour cities in the Asia-Pacific region, including Shanghai, Hong Kong, Tokyo, Okinawa, Singapore, Bangkok, Batavia, Surabaya, Celebes, Guam, Honolulu, and San Francisco (Maglipon 1993, 95; Pope 1966, 42). Forming an early part of a lineage of Filipino migrants such as musicians and boxers who provided entertainment in nearby port cities (S. Lewis 2016, 88, 235), he was adept at accommodating an array of contrasting practices and expectations.

Like Canuplin, the indigenous trickster archetype invoked by Kenkoy typically finds itself thrown into an unfamiliar and disorienting situation whose norms he fails to master (S. Reyes 2009, 395). Attired in an oversized white cotton suit with his hair slicked back with pomade, Kenkoy speaks in broken English with cannibalized words like "Bay-gali," "Beri," and "Wat-sa-mara." The disjointed language that he uses reveals the difficulty in smoothly reconciling seemingly incongruous realities during this period. Episodes in the serial comic strip examine the tentative, everyday attempts of Filipinos to assimilate the novel lifestyles disseminated by US culture (S. Reyes 2009, 394-95). Coming at the expense of its protagonist, the comic strip's vaudevillian humor compensated for the humiliating awkwardness of these efforts, which always result in failure.

Psychologist Jaime Bulatao (1964) explains how the normative behavior of Filipinos appears to be determined by hiya, which he describes as an overwhelming feeling of shyness, timidity, or embarrassment. According to Bulatao, hiya often materializes in an unfamiliar and disorienting situation that is beyond the capacity of an individual to comprehend or control. Unable to cope with the perceived judgment of the public, the individual grows anxious and elusive almost to the point of paralysis. Working with this provisional concept, I would suggest that Filipinos before the Pacific War experienced their encounter with modernity as a disorienting situation, in which they confronted unfamiliar realities without having the knowledge or capability to do so. The debilitating experience of hiya kept them from experimenting with untested adaptations, whose awkward performance could easily result in embarrassment. As depicted in the exaggerated physicality of Kenkoy, modernity forced a transformation to their bodies, which allowed them to manage unpredictable realities with their existing capacities. They needed to rely on the aid of consumer products and lifestyles to be able to alter their appearance, behavior, and attitude. This reconfiguration of bodily capacities included making the feeling of embarrassment more acceptable as part of their assimilation into modernity. As a transitional figure, Kenkoy demonstrates how embarrassment could be embraced in dealing with modern forces despite the possible awkwardness or failure of the encounter.

Accentuating their transcendent newness, the discourses that circulated through local periodicals promoted the capacity of modern commodities to deliver the miraculous benefits of modernity to everyday life. Embodied in the transformative products of technological advances, the profound changes introduced by modern forces were commonly perceived to be supernatural and divine (McClintock 1995, 221-22), beyond the reach of ordinary people to generate without an interceding agency. For those unaccustomed to modern realities, they functioned almost like sacred objects such as anting-anting, which are believed to be founts of divine power. Reynaldo Ileto $(1979,25)$ describes how these amulets would be used to enhance the strength and authority of their wielders. Although 
consumer items may not have shared their mystical provenance, they were likewise tapped as means for overcoming the limitations of the natural body. The notion of them as sources of transcendental power augmented the capacity of their owners to grapple with seemingly inscrutable and uncontrollable modern forces.

Exemplifying tendencies in the Filipino print and visual culture of the time with their recurrent use of the word "modern" and its connotations, local advertisements for consumer items differed from those in the United States, which mainly focused on social reputation and mobility during this period (Marchand 1985; Vinikas 1992). Drawing on the entanglement between modernity and sanitation, an advertisement for Ivory soap from the 1930s offered to introduce the miraculous modern conditions of cleanliness, health, and happiness to the lives of consumers at the price of only a few centavos: "A little thing like Ivory soap-bringing you the blessing of cleanliness, as the first aid to good health-plays an important part in your happiness and enjoyment of life.... Form the Ivory habit. Take advantage of the cleansing Ivory lather to keep yourself in the pink of physical condition. Ivory for bath, Ivory for face and hands-washes away more than dirt and the stain's impurities. It washes away the blues-makes life seem better and brighter."

In the advertisement, Ivory soap is transfigured into a sacred object, whose "blessing of cleanliness" would bestow "good health" through faithful use. Although seemingly inconsequential because of its size and appearance, this commodity is presented in the ad with the supernatural capacity to purge undesirable elements such as germs and sorrows. As one of its main selling points, the newness of the product derived its value from the transcendent intervention it offered, a capacity that was typically inaccessible to ordinary people. The advertisement presents modern sanitation as the continuous process of eliminating undesirable realities from bodies, which entails the simultaneous application of technological advances and repetition of hygienic practices (Vinikas 1992, 97). But because Filipino consumers may have found modern realities to be unfamiliar and unmanageable, their adoption of them through the interceding agency of this object required flexibility and persistence. Only if they embraced as their "habit" the activity of washing their bodies with Ivory soap would they find the bliss of heavenly paradise on earth.

As increasing numbers of Filipino women entered the workforce, they were heralded in the public culture as examples of ordinary consumers who could harness the possibilities of consumption for modern self-fashioning. The stereotypical image of a traditional Filipino woman had been founded on Rizal's fictional character of Maria Clara, whom he portrays as being sentimental, genteel, shy, and docile. Local periodicals aimed to educate their female readers about how to behave in social settings and engage in leisure practices. In an essay in the Philippines Free Press (1932a), a salesperson on Calle Escolta explains that the allure of the multiplicity of products in the commercial street compelled her to seek employment, through which she could gain her own purchasing power instead of relying on the financial support of her husband. According to her account, her difficult dealings with male customers who would flirt and haggle with her motivated her to learn how to conquer her "original shyness" or hiya with modern self-assuredness and "sophisticat[ion]."

As the main commercial street of the colonial capital, the Escolta was a site where Filipinos could encounter and negotiate modern realities through capitalist consumption. 
But because urban modernity was embodied in superlative structures, most ordinary people aspired and struggled to accommodate its forces in their usage of consumer and media products with flexibility and creativity akin to the medium of vaudeville. Despite their desire and effort, the promise of modernity tended to exceed their grasp.

\section{0s Avenida Rizal: Modernity as Youthful Dynamism}

This promise threatened to dissipate with the harrowing devastation and privation of the Pacific War and the Japanese occupation, which tested the limits of existing systems of capitalism and infrastructures of modernization (Doeppers 2016, 333-34), but the return of the US presence and the declaration of Philippine sovereignty offered Filipinos the optimism of a new start. By the 1960s, the Philippines had experienced political independence from the United States for almost two decades, although pundits decried the abiding influence of the latter over its affairs. Led now by Filipinos, the government aspired to realize the opportunities of self-determination by demonstrating its ability to bring economic progress to the nation through the protection and cultivation of local industries. Although hounded by allegations of corruption, the government of Ferdinand Marcos represented a robust form of modernization (Espiritu 2017, 52-56) that desired to mimic the top-down economic development initiated by authoritarian states in nearby Asian nations such as Singapore and Taiwan, which violently transformed the cityscape into sites of industrial production and social order (Watson 2011, 101-3). In the most widely circulated newspapers and magazines of the period like the Manila Times, Manila Chronicle, Philippines Free Press, and Philippine Graphic, the nation was described to be in a "pre-take-off" stage. With the large increase in the urban population, the awareness grew in the public culture that, unlike in the 1930s, the possibilities of modernity were no longer restricted to the transcendent interventions of government and business but also manifested in the immanent dynamism of ordinary people.

In contrast to the general impression of imminent economic growth, the nation was repeatedly characterized in local periodicals of the time as inescapably mired in crime, violence, poverty, and congestion. This characterization revealed the prevailing inequality between members of the elite and the majority of the populace in terms of not only the amount of wealth but also the scope of action. News reportage highlighted the entrenched corruption, in the form of bribery, smuggling, and racketeering, which hindered political institutions from operating effectively to sustain economic growth and establish social order. According to the crime statistics of the National Bureau of Investigation, a sexual offense was committed every two hours, and a murder every hour (Philippine Graphic 1967). Because violations of the law were not equally prosecuted and punished, people acted as if they could disregard its norms with impunity (De Manila $1968,5)$. Ranajit Guha (1999) argues that an increase in the frequency of illegal activity implies the burgeoning energy in the populace to resist institutions of authority. This state of impunity, in which individuals were free to perform acts of violence without fear of justice, restrained the economic opportunities for national development while expanding the epistemological possibilities of personal agency.

With the outbreak of the Pacific War, the urban nucleus of Manila shifted from Calle Escolta to Rizal Avenue as the composition of its populace changed. Whereas the Escolta 
continued to be the heart of financial activity, it was the Avenida that now captivated the popular imagination. At the beginning and conclusion of the war, many of Manila's inhabitants had fled to the nearby suburbs and provinces to escape the turmoil of invasion and liberation (Doeppers 2016, 309-10, 326-27). This exodus was followed by the influx of tens of thousands of migrants from across the archipelago because the city served as the center for the distribution of relief goods to war survivors and refugees. The destruction to farmland and livestock from the war deprived families of important agricultural resources, which they had relied on for their livelihood. The mass internal migration of Filipinos to the city continued over the next decade with the escalation of the Hukbalahap rebellion in Central Luzon (Alcazaren, Ferrer, and Icamina 2011, 61-62). Driven by the scarcity of resources and opportunities in their localities, they were allured by the potent image of Manila as a promised land, which would deliver its inhabitants from poverty. Among the various districts that comprised Manila, the Avenida captured their imagination the most because it was the first commercial area that internal migrants would visit upon their arrival at Tutuban railway station, where they would supposedly trade their everyday sandals in the province for the shoes vital for life in the metropolis (Ira, Medina, and Ricio 1977, 99).

Rizal Avenue, or the Avenida as it was more commonly called, represents the reconfiguration of the commercial street from an exclusive enclosure of conspicuous consumption into a bustling hub of popular leisure. With the rapid growth in the urban population, the main commercial street in 1960s Manila no longer derived its centrality from its epitome of prestige and progress but instead had become the favored destination where Filipinos, regardless of class or gender, could have easy access to affordable products and commercial movies. From serving as a means for ascending the established hierarchy, as it had in prior historical periods, it now functioned as a venue for participating in mass activity. In this milieu, the Avenida attained popularity as "Downtown," a term of affection that connoted a concentration of humanity.

Rizal Avenue stretches for five kilometers to Caloocan, but it was the busy shopping district from Carriedo Street to Claro M. Recto Avenue that grew to be synonymous with the name Avenida. This section of Rizal Avenue forms a straightforward path across a labyrinth of shorter and narrower roads and alleyways dating to the Spanish regime. Between Carriedo and Recto, the four winding streets that intersected with Rizal Avenue-Bustos, Ronquillo, Raon, and Soler-contained the surplus of corporeal and commercial activity from the main thoroughfare, which spilled over into the immediately surrounding areas.

The Avenida was famous for its multiplicity of affordable goods, which could be found in the shelves and bins of its stores at cheaper prices than in those of the Escolta. Even if the centrality of the cityscape had shifted to Rizal Avenue, Escolta Street retained its prominence as a source of luxury items. Along Rizal Avenue, many of the stores that carried affordable goods were called emporiums, which were less regimented and more informal versions of the typical department store. According to accounts in newspapers and memoirs, they were "democratic" in their accessibility to consumers with stocks of everyday household goods and electronic products such as electric pans, plastic flowers, ceramic elephants, pocket calculators, and cassette recorders (Ira et al. 1977, 99). The historical period was likewise marked by the proliferation and popularity in the metropolis of brands and stores of leather and rubber shoes. Rizal 
Avenue and adjacent Carriedo Street were both lined by shops and emporiums that sold shoes of all shapes, colors, and designs, which signified the prevailing tendencies of the time of mobility and self-transformation. Whereas the Avenida had been dominated by Japanese shops before the Pacific War, it was now the site of thriving Filipino businesses. The success of the local shoe industry was the result of "Filipino First" economic nationalism, an idea with much currency as a governmental policy that regulated the influx of imported goods and nurtured the growth of local businesses at the expense of the prosperous ethnic Chinese (Cullather 1994, 165-66, 172), who were perceived to embody foreign capital that needed to be overcome (Hau 2014, 149-50).

With more mass products and services being offered in the low-rise buildings in the different streets perpendicular to Avenida Rizal, the area was a profusion of commercial activity. On Ronquillo, the western part of which runs alongside Bustos, people could have lighters repaired and stamps manufactured. Those in search of metal tools and spare parts visited Soler, which passes in between Recto and Raon. Although it was home to printing houses, dental clinics, and billiard halls, Raon was mainly known as a site where phonograph records, musical instruments, and transistor radios could be tested and purchased. In the public culture, it was christened Manila's noisiest street (Ira et al. 1977, 109), perhaps due to the dissonance of radio and stereo speakers blaring at full volume that competed with the cacophony of cars, buses, and jeepneys rumbling, honking, and screeching at the same time. This frenetic, overwhelming bustle of everyday life in 1960s Manila was encapsulated in the urgent language of Edgardo M. Reyes' (1986, 143) Sa Mga Kuko ng Liwanag (In the Claws of Neon), a social realist novel serialized in Liwayway from 1966 to 1967.

The Avenida's popularity rested moreover on its famous neon-lit movie theaters, where Filipinos of different classes and genders converged in the same spaces to watch the latest features. The Tagalog film industry's heyday was in the 1950s and early 1960s, when major local studios Sampaguita, LVN, Premiere, and Lebran dominated the landscape of the city with their star-driven genre pictures. Lining Rizal Avenue for several blocks, many of these theaters-such as the State, Ever, Avenue, and Scala-were designed in the art deco style with polygonal structures, angular corners, and rectilinear striations by prominent Filipino architects like Juan Nakpil and Pablo Antonio. Among the movie houses that drew the largest crowds of people was the Ideal Theater, a landmark that had stood at the entrance to Avenida Rizal via Carriedo Street since 1933. It was dedicated to screening new productions from the major Hollywood studio Metro-Goldwyn-Mayer or MGM, which was known for its glamorous, big-budget musicals (Schatz 1996, 440). If the Crystal Arcade symbolized the exclusive distinction of Calle Escolta during the 1930s, the Ideal Theater embodied the popular appeal of Avenida Rizal during the 1960s. By sharing an affinity for their favorite stars in the intimate enclosures of packed, "standing-room-only" movie houses, urban residents could participate in an imagined multitude of likeminded spectators.

While produced and circulated primarily for profit, such media spectacles did not necessarily induce docility and atomization in audiences. Their presentation of their movie stars created new conditions of possibility for transforming the established order by offering vernacular models of emulation for ordinary people to exceed the necessity of everyday life through the refashioning of their appearance, gestures, and lifestyle. In the 1960s, the most popular actors were Fernando Poe Jr. and Joseph Estrada, 
whose masculine personas embodied the anomie and disquiet of youth typical of this historical moment. Decades later, these movie stars exploited their immense popularity at the box office by successfully campaigning for the presidency.

On the screen, Fernando Poe Jr. assumed the character of an incorruptible, taciturn individual who avenges his persecution by villainous forces. Painted as mythic in stature (De Manila 1977d, 6) in films such as Markado (1960) and Daniel Barrion (1964), his hero, Daniel Barrion, leads ordinary peasants to struggle for their rights despite their marginalization. Falsely accused and ruthlessly oppressed, he refrains from seeking justice until being pushed to the limit of his forbearance. In movies like Asiong Salonga (1961) and Geron Busabos, Ang Batang Quiapo (1964), Joseph Estrada tended to play social misfits, whose outlook and behavior have been roughened by their experience of urban poverty. While regarded as an unschooled hooligan due to his uncouth and impetuous actions, his protagonist, Gerun Busabos, holds a strong sense of justice for the downtrodden even though it may conflict with the arbitrary enforcement of the law by the police. Having gained widespread significance as cultural archetypes, the position of these cinematic personas in relation to the dominant hierarchy challenged the norms of possibility for self-transformation.

In contrast to 1930s modernity, which rested on the prodigious efficacy of powerful institutions and organizations, the allure of movie stardom existed partly because it exhibited elements of its mundane origins. Reflecting the paradoxical duality of 1960s modernity, the movie stars of the time stood apart from the multitude while continuing to belong to it. Their cinematic personas vigorously transcended the conditions of poverty and oppression without ever purging them entirely from the makeup of their identity. Because traces of everyday realities remained visible in them, the images of movie stars fostered the notion among the public that the mundane could suddenly be transmuted into the extraordinary. The allure of the movie star derived from this transformative potential, which was shaped by a stance of defiance toward dominant norms of hierarchy and advancement.

Despite validating the established order as mass commodities of the entertainment industry, the generic conventions of popular movies can become transgressive when they feature protagonists who visibly resist dominant norms (Altman 1999, 149). The cinematic personas of Fernando Poe Jr. and Joseph Estrada typically refused the terms of the established order, which perpetuated the subjugation of the poor. Subverting the custom that the youth submit to authority, their stubborn defiance departed from the awkward embrace by 1930s vaudeville performers of urban flows by demanding a form of justice that, having no place under prevailing conditions, their multitudes of fans likewise desired. The commonality of witnessing this refusal onscreen created an unspoken connection among viewers who derived pleasure from them (Altman 1999, 158). Perhaps more so than news reportage about the violent struggle of Hukbalahap revolutionaries, such media spectacles furnished ordinary people with new modes of expression and sociality, which enabled them to redefine the parameters of agency in the landscape of the city.

In the public culture of 1960s Manila, the word "modern" still denoted the intervening presence of newness in the routine of everyday life, albeit with a different meaning. Although the advertising industry in the United States turned to motifs of youthful freedom and self-realization during this period (Frank 1998, 15), it seldom deployed 
the language of modernity. In contrast, local advertisements tried to tap into modernity's continued popularity and resonance by closely associating their products with this phenomenon. Instead of relying on striking descriptors to generate appeal, they emphasized the transformative capacity of commodities for bringing something new into the world. Whereas newness in the 1930s connoted a form of divine intervention, which stayed inaccessible to ordinary people, newness in the 1960s bore the meaning of an inner potential, which could erupt at any moment.

In comparison with local soap advertisements in the 1930s, an advertisement for Life Buoy soap, which frequently appeared in newspapers in the mid-1960s, presented it as a daily necessity for "active, modern people" with its "new, vigorous" composition. Accompanied by a caption, which describes the product as having a "new perfume, new germicide, new shape, new color, [and] new pack," the picture in the advertisement is divided into three frames, which show both young men and women engaged in different youthful activities like sports and dancing with poses and gestures evoking tireless movement. The series of images is used to indicate dynamism, whose vigorous character can only be visualized through a succession of similar yet varied depictions.

A series of local advertisements for 7-Up, which was consumed in the many popular soda parlors along Rizal Avenue, proclaimed the soft drink to be crucial for activity: "Whew! Jerking's real action and gets you all warmed up... It's got the sparkle that swings... The taste that's fresh and frisky... Dance time ... anytime ... get 7-Up!" With language that conveys the speed and breathlessness of the historical moment, people are characterized as being restless and in constant motion. Print advertisements in other Southeast Asian cities such as Bangkok, Kuala Lumpur, and Singapore likewise featured young people being refreshed by soft drinks but without the same iconography of irrepressible collective urgency. Departing from its configuration during the 1930s, newness in the advertisements circulated in Philippine periodicals during the 1960s no longer depicted the transformative force of modernity as originating decisively from beyond the urban domain but as issuing unexpectedly from within autonomous bodies. Any space in the cityscape was imagined as having the potential to become a site of agency, to be seized spontaneously at any instant for the sake of discharging restive energy.

In the public culture of the time, modern life signified youthful dynamism, restless activity, and vigorous transformation. Roughly two-thirds of the Philippine population during this period were aged twenty-four and below (Zapanta 1966, 46). In Manila, approximately half of the residents were younger than seventeen (Social Welfare Department 1967, 91). Prominent and popular local periodicals, novels, advertisements, and films recurrently depicted the Filipino youth as being dynamic individuals who restlessly needed to expend their surplus energy.

In the 1930s, modernity was experienced as an uncontrollable, monolithic force, which was embodied in the architecture, merchandise, and technology of the time. By the 1960s, individuals possessed a greater sense of their rights and abilities, particularly their capacity to bring about transformation. Driven by newfound passion and confidence, they apprehended modernity as a constellation of possibilities that they themselves could actualize. In periodical articles published during this period under his journalistic pseudonym Quijano de Manila, Nick Joaquin (De Manila [1977c] 2009, 63) defined youth as a disposition that blurs the boundaries between imagination and 
reality. Enthusiastic about future possibilities, the youth fervidly produce countless ideas for transforming the established order. They are endowed with the energy to give these ideas a concrete presence in the world, but, being anxious and tentative, they helplessly flounder without the know-how to realize their aspirations.

Embodying the central tendency of this historical moment, the most prominent politicians during this period were youthful, spontaneous, and energetic figures. News photographs in local periodicals liked to depict them in an array of vigorous poses, chatting and orating with various types of lively expressions etched on their faces. They were recognized in the public culture as being dynamic, a quality that became equated with the capacity for transformation. Presented as vernacular models for emulation, whose appearances and gestures were to be consumed like commodities, these public personas fashioned themselves as active builders of the infrastructure of the nation. Whereas Kenkoy tentatively struggled to harness modern forces, such monumental figures seemed to possess the confidence and ability to translate vision into reality.

In a time defined by politics, even Filipino politicians vied to be identified with the youth, an important segment of the electorate. For Nick Joaquin, 1950s Philippine President Ramon Magsaysay and Manila Mayor Arsenio Lacson epitomized the new, dynamic type of national leader appropriate to the historical moment. Joaquin contrasted Magsaysay and Lacson with the dominant political persona before the Pacific War, Philippine Commonwealth President Manuel Quezon, whom he characterized as being imperious and jaded (De Manila 1977a, 33). According to Joaquin (De Manila 1977a, 34), national leaders during Quezon's time were considered demigods whose unique talent and upbringing bestowed on them the quality and right to govern. This impression corresponded with the perception of modern forces during the 1930s as being governable only by superlative figures.

Many of these figures were regularly featured in the pages of daily periodicals and news magazines. Embodying the tenacious dynamism of 1960s Manila, Manila Mayor Antonio J. Villegas stood six feet tall with a boyish face and a brawler's jaw (De Manila [1981] 2013, 90). Another one of Magsaysay's youthful, idealistic adherents, Villegas liked to style himself as a popular movie star whose valiant feats would bring salvation to a once glorious city now mired in poverty and squalor. The symbol of his office, a sunburst, resounded with the spontaneous energy of his signature interjection of salutation and triumph, "Yeba!" (De Manila 1965, 50). Exhibiting movie stardom's paradoxical duality of ordinariness and transcendence, Villegas's flamboyant public persona celebrated his rapid rise from the blighted communities of Tondo: "He has daring and determination-afire with ambition, impatient with the humdrum, in a hurry to grow up, always on the lookout for the quickest way to get where he wants to go, never letting any opportunity pass unexploited" (Rama 1968, 2). With a fierce resolve that was free of the awkward tentativeness of Canuplin or Kenkoy, he strived to rekindle the promise of Manila with the assumption that the path of national development required the restless pursuit of activity, without which it could become easily undone.

Accompanying the exponential increase in the population, the prevalence of youthful modernity in the Philippines corresponded with the proliferation of new modes of expression and sociality. Whereas US print culture emphasized individuality (Frank 1998, 59), local periodicals characterized the restless and energetic activity of ordinary young men and women as being necessarily collective. Historian Vicente Rafael (2000, 
154) highlights how their participation in all types of groups-including gangs, bands, unions, parties, and crowds-defined their identity as youth. Young people liked to spend their leisure time away from school or work by idling with their barkada, their exclusive gang of bosom friends. Dissatisfied with the norms of the established order, the youth held their barkada in greater esteem than their family (De Manila [1977c] 2009, 67).

The proliferation of new forms of collectivity indicated a growing restiveness among the multitudes of Filipinos. According to Nick Joaquin, young Filipinos who desired change contested the terms of the established order with a stance of stubborn defiance, which emulated that of movie stars during this period. Their actions echoed the global tendency of the time for revolutionary agency. Withdrawing from normative enclosures of hierarchy and discipline such as homes, offices, and classrooms, they would occupy the public spaces of roads and plazas, which they used not for transit or leisure but for dissent and protest (Rafael 2000, 155). Like in the spontaneous assemblies of young radicals in 1960s Tokyo (Sand 2013, 45), the urban landscape of Manila became reimagined and infused with the vitality of boundless possibility.

If modernity in the 1930s was awkward because its manifestations seemed transcendent and inaccessible to most people, the tentativeness of modernity in the 1960s manifested in representations of the youth, which highlighted the constant opposition and oscillation between the states of idleness and vitality. On the one hand, this ambivalence signaled the possibility of the sudden translation of the mundane into the extraordinary, which typified the paradoxical duality of movie stardom. On other hand, it betrayed the uncertainty surrounding the persistent problems of rampant violent crime and lackluster economic growth, which had beset the nation.

According to a recurrent motif in the public culture of the time, to be idle was to be a nonproductive member of society like the "kanto boys" and "istambays," shiftless, indigent men who spent their time "standing by" the "kantos" or "corners" of neighborhood stores. This archetype of withdrawal from the established order was exemplified by Joseph Estrada's cinematic antiheros, who often loitered in urban spaces, performing intermittent jobs while helping their fellow marginalized. Refusing the model of the dynamic public figures that strove to be nation builders, idlers insouciantly waited for opportunities to arrive instead of actively seeking them out. The transformative potential they carried as youthful individuals was left untapped. While it highlighted a change in the understanding of how inertness could be a venue for the spontaneous eruption of energy, it disclosed how this energy could quickly dissipate if unmanaged without object or resolve.

Carmen Guerrero Nakpil $(1966,10)$ reflected on the larger implications of this disposition in her newspaper column: "One of the griefs of running this country (or trying to run it, anyway) is that the people are too un-tense, too relaxed and incapable of anger.... One more barrio fiesta and bahala na." The Filipino idiom of bahala na could be literally translated as, "Leave it to God to take care of it." For Nakpil, the idleness of the stance of bahala na assumed the form of indifference and passivity, which supplanted effective governance with a fatalistic surrender to the contingency of reality. Diverging from this view, Rafael $(2010,157)$ embraces the transformative potential inherent in bahala $n a$ as "a willingness to expose oneself to chance, to face the unknown which is yet to have a face, ... to be free for a future that is yet to come." Whereas Nakpil characterizes 
bahala na as a negative response of inaction towards the helpless expectancy of an uncontrollable future, Rafael understands this surrender to uncertainty more as an openness to the possibility of change.

Taken in this light, the ambivalent oscillation between the mundane and the extraordinary revealed the promise of revolutionary agency. The boundary that separated idleness from vitality was recurrently depicted in the public culture of the time as being tenuous. In an evocative news article from the period, Jose Lacaba ([1982] 2003, 17) described a protest rally comprised mainly of the youth on the first day of the new congressional season: "And suddenly, what had earlier seemed a most sluggish, spineless, easygoing, disorganized assortment of oddniks was galvanized into a cohesive force, about a thousand strong, that rose as one." Investing his account with a breathless succession of adjectives to approximate the excitement of the moment, Lacaba stages the event as a battle between impassive government forces and impassioned young citizens. With the dynamic language of modernity, he uses the contrast between idleness and vitality to demonstrate how the urgency of social upheaval can immanently reconfigure seemingly idle bodies into a dynamic collective.

The potency of consumer and media products in 1930s and 1960s Manila unveils the complexity of the imagination and experience of capitalist modernity in an Asian city in the Global South. For Rafael, the stance of bahala na presents itself as a vital condition of possibility for the sudden introduction of something new into the world, which could provoke the overturning of the established order. Tracing the tenuous boundary between the transcendent intervention of government and business and the immanent dynamism of the multitude, it discloses how the structures and meanings of modernity are not predetermined but provisional. Instead of merely being the root of fatalistic resignation to the necessity of reality, it is this contingency, not so much rationality, efficacy, or violence, that is the source of modernity's transformative force.

\section{List of References}

Agoncillo, Teodoro. 2003. "Manila in the 1890s." In History and Culture, Language and Literature: Selected Essays of Teodoro Agoncillo, ed. Bernadita Reyes Churchill, 317-37. Manila: University of Santo Tomas Publishing House.

Alcazaren, Paulo, Luis Ferrer, and Benvenuto Icamina. 2011. Lungsod Iskwater: The Evolution of Informality as a Dominant Pattern in Philippine Cities. Mandaluyong City, Philippines: Anvil.

Altman, Rick. 1999. Film/Genre. London: BFI Publishing.

Anderson, Warwick. 2006. Colonial Pathologies: American Tropical Medicine, Race, and Hygiene in the Philippines. Durham, N.C.: Duke University Press.

Appadurai, Arjun. 1996. Modernity at Large: Cultural Dimensions of Globalization. Minneapolis: University of Minnesota Press.

Bulatao, Jaime C. 1964. "Hiya." Philippine Studies 12(3):424-38.

Canclini, Néstor García. 1995. Hybrid Cultures: Strategies for Entering and Leaving Modernity. Translated by Christopher L. Chiappari and Silvia L. Lopez. Minneapolis: University of Minnesota Press. 
Cohen, Matthew Isaac. 2006. The Komedie Stamboel: Popular Theater in Colonial Indonesia, 1891-1903. Athens: Ohio University Center for International Studies.

Cullather, Nick. 1994. Illusions of Influence: The Political Economy of United StatesPhilippines Relations, 1942-1960. Stanford, Calif.: Stanford University Press.

De Manila, Quijano [Nick Joaquin]. 1965. "The Manila of His Affections." Philippines Free Press, June 26.

. 1968. "The Unkindest Cut.” Philippines Free Press, February 17.

. 1977a. Gloria Diaz and Other Delineations. Quezon City: National Bookstore.

1977b. Manila: Sin City? and Other Chronicles. Quezon City: National Bookstore. . [1977c] 2009. Reportage on Crime: Thirteen Horror Happenings That Hit the Headlines. Manila: Anvil.

1977d. Ronnie Poe and Other Silhouettes. Quezon City: National Bookstore.

—. [1981] 2013. Reportage on Politics. Manila: Anvil.

Doeppers, Daniel F. 1984. Manila, 1900-1941: Social Change in a Late Colonial Metropolis. New Haven, Conn.: Yale University Southeast Asian Studies.

—. 2016. Feeding Manila in Peace and War, 1850-1945. Madison: University of Wisconsin Press.

Espiritu, Talitha. 2017. Passionate Revolutions: The Media and the Rise and Fall of the Marcos Regime. Athens: Ohio University Press.

Frank, Thomas. 1998. The Conquest of Cool: Business Culture, Counterculture, and the Rise of Hip Consumerism. Chicago: University of Chicago Press.

Guha, Ranajti 1999. Elementary Aspects of Peasant Insurgency in Colonial India. Durham, N.C.: Duke University Press.

Hau, Caroline S. 2014. The Chinese Question: Ethnicity, Nation, and Region in and beyond the Philippines. Singapore: NUS Press.

Ileto, Reynaldo C. 1979. Pasyon and Revolution: Popular Movements in the Philippines, 1840-1910. Quezon City: Ateneo de Manila University Press.

Ira, Luning B., Isagani R. Medina, and Nik Ricio. 1977. Streets of Manila. Quezon City: GCF Books.

Jenkins, Henry. 1992. What Made Pistachio Nuts? Early Sound Comedy and the Vaudeville Aesthetic. New York: Columbia University Press.

José, F. Sionil. 2004. "Manila 7 Decades Ago." Philippine Star, May 9.

Kramer, Paul A. 2006. The Blood of Government: Race, Empire, the United States, and the Philippines. Chapel Hill: University of North Carolina Press.

Lacaba, Jose F. [1982] 2003. Days of Disquiet, Days of Rage: The First Quarter Storm and Related Events. Manila: Anvil.

Leach, William. 1993. Land of Desire: Merchants, Power, and the Rise of a New American Culture. New York: Vintage.

Lee, Leo Ou-Fan. 1999. Shanghai Modern: The Flowering of a New Urban Culture in China, 1930-1945. Cambridge, Mass.: Harvard University Press.

Lewis, Robert M. 2003. From Traveling Show to Vaudeville: Theatrical Spectacle in America, 1830-1910. Baltimore: John Hopkins University Press.

Lewis, Su Lin. 2016. Cities in Motion: Urban Life and Cosmopolitanism in Southeast Asia, 1920-1940. Cambridge: Cambridge University Press.

Maglipon, Jo-Ann Q. 1993. “Canuplin: The Little Tramp Time Left Behind.” In Primed: Selected Stories 1972-1992, 94-103. Manila: Anvil.

Manila DaILY BulLETIN. 1932. June 1.

Marchand, Roland. 1985. Advertising the American Dream: Making Way for Modernity, 1920-1940. Berkeley: University of California Press. 
McClintock, Ann. 1995. Imperial Leather: Race, Gender, Sexuality in the Colonial Conquest. New York: Routledge.

Mrázek, Rudolf. 2002. Engineers of Happy Land: Technology and Nationalism in a Colony. Princeton, N.J.: Princeton University Press.

Nakpil, Carmen Guerrero. 1966. "Crime and Crisis." Sunday Times Magazine, July 31.

Pang, Laikwan. 2012. Creativity and Its Discontents: China's Creative Industries and Intellectual Property Rights Offenses. Durham, N.C.: Duke University Press.

Pérez, Louis A. Jr. 1999. On Becoming Cuban: Identity, Nationality, and Culture. Chapel Hill: University of North Carolina Press.

Philippine Graphic. 1967. August 16.

Philippines Free Press. 1932a. "Confessions of a Beautiful Shopgirl.” September 24.

—. 1932b. "To Bring Back Vaudeville." September 17.

Philippines Herald Yearbook. 1933. "Filipino Participation In Business." September 23.

Pope, Jean. 1966. “The Limelight That Waned.” Sunday Times Magazine, October 9.

Rafael, Vicente L. 2000. White Love: And Other Events in Philippine History. Durham, N.C.: Duke University Press.

—. 2010. "Welcoming What Comes: Sovereignty and Revolution in the Colonial Philippines." Comparative Studies in Society and History 52(1):157-79.

Rama, Napoleon G. 1968. “Go! Go! Go!” Philippines Free Press, March 30.

Reyes, Edgardo M. 1986. Sa Mga Kuko ng Liwanag [In the Claws of Neon]. Manila: De La Salle University Press.

Reyes, Soledad S. 2009. "The Komiks and Retelling the Lore of the Folk." Philippine Studies 57(3):389-417.

Rizal, José. 2006. Noli Me Tangere (Touch Me Not). Translated by Harold Augenbraum. New York: Penguin Classics.

SAnd, Jordan. 2013. Tokyo Vernacular: Common Spaces, Local Histories, Found Objects. Berkeley: University of California Press.

Schatz, Thomas. 1996. The Genius of the System: Hollywood Filmmaking in the Studio Era. New York: Henry Holt.

Social Welfare Department. 1967. Manila: Its Needs and Resources. Manila: Social Welfare Department.

Sunday Times Magazine. 1950. "Escolta Lensmen.” June 25.

Ventura, Sylvia Mendez. 1978. "Earthquakes, Typhoons, Floods, and Other Acts of God.” In Turn of the Century, eds. Gilda Cordero-Fernando and Nik Ricio, 197201. Quezon City: GCF Books.

Vinikas, Vincent. 1992. Soft Soap, Hard Sell: American Hygiene in an Age of Advertisement. Ames: Iowa State University Press.

Watson, Jini Kim. 2011. The New Asian City: Three Dimensional Fictions of Space and Urban Form. Minneapolis: University of Minnesota Press.

Williams, Raymond. 1977. Marxism and Literature. Oxford: Oxford University Press.

Zapanta, P. A. 1966. "In the National Headcount, the Youths Have It." Sunday Times Magazine, October 30.

Zhang, Zhen. 2005. An Amorous History of the Silver Screen: Shanghai Cinema, 18961937. Chicago: University of Chicago Press. 